\title{
Mid-Pliocene East Asian monsoon climate simulated in the PlioMIP
}

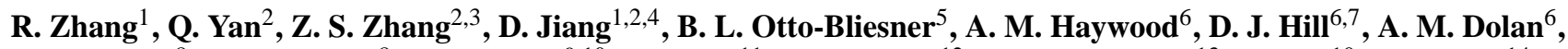 \\ C. Stepanek $^{8}$, G. Lohmann ${ }^{8}$, C. Contoux ${ }^{9,10}$, F. Bragg ${ }^{11}$, W.-L. Chan ${ }^{12}$, M. A. Chandler ${ }^{13}$, A. Jost ${ }^{10}$, Y. Kamae ${ }^{14}$, \\ A. Abe-Ouchi ${ }^{12,15}$, G. Ramstein ${ }^{9}$, N. A. Rosenbloom ${ }^{5}$, L. Sohl ${ }^{13}$, and H. Ueda ${ }^{14}$ \\ ${ }^{1}$ Climate Change Research Center, Chinese Academy of Sciences, Beijing 100029, China \\ ${ }^{2}$ Nansen-Zhu International Research Centre, Institute of Atmospheric Physics, Chinese Academy of Sciences, Beijing \\ 100029, China \\ ${ }^{3}$ UniResearch, Bjerknes Centre for Climate Research, Bergen 5007, Norway \\ ${ }^{4}$ Key Laboratory of Regional Climate-Environment Research for Temperate East Asia, Chinese Academy of Sciences, \\ Beijing 100029, China \\ ${ }^{5}$ National Center for Atmospheric Research, Boulder, Colorado, USA \\ ${ }^{6}$ School of Earth and Environment, University of Leeds, Woodhouse Lane, Leeds, LS29JT, UK \\ ${ }^{7}$ British Geological Survey, Keyworth, Nottingham, NG12 5GG, UK \\ ${ }^{8}$ Alfred Wegener Institute, Helmholtz Centre for Polar and Marine Research, Bremerhaven, Germany \\ ${ }^{9}$ LSCE/IPSL, CNRS-CEA-UVSQ, Saclay, France \\ ${ }^{10}$ Sisyphe, CNRS/UPMC Univ Paris 06, Paris, France \\ ${ }^{11}$ School of Geographical Sciences, University of Bristol, University Road, Bristol, BS8 1SS, UK \\ ${ }^{12}$ Atmosphere and Ocean Research Institute, University of Tokyo, Kashiwa, Japan \\ ${ }^{13}$ Columbia University-NASA/GISS, New York, NY, USA \\ ${ }^{14}$ Graduate School of Life and Environmental Sciences, University of Tsukuba, Tsukuba, Japan \\ ${ }^{15}$ Research Institute for Global Change, JAMSTEC, Yokohama, Japan
}

Correspondence to: Z. S. Zhang (zhongshi.zhang@bjerknes.uib.no)

Received: 22 February 2013 - Published in Clim. Past Discuss.: 28 February 2013

Revised: 10 July 2013 - Accepted: 22 July 2013 - Published: 3 September 2013

\begin{abstract}
Based on simulations with 15 climate models in the Pliocene Model Intercomparison Project (PlioMIP), the regional climate of East Asia (focusing on China) during the mid-Pliocene is investigated in this study. Compared to the pre-industrial, the multi-model ensemble mean (MMM) of all models shows the East Asian summer winds (EASWs) largely strengthen in monsoon China, and the East Asian winter winds (EAWWs) strengthen in south monsoon China but slightly weaken in north monsoon China in the mid-Pliocene. The MMM of all models also illustrates a warmer and wetter mid-Pliocene climate in China. The simulated weakened mid-Pliocene EAWWs in north monsoon China and intensified EASWs in monsoon China agree well with geological reconstructions. However, there is a large model-model discrepancy in simulating mid-Pliocene EAWW, which should be further addressed in the future work of PlioMIP.
\end{abstract}

\section{Introduction}

The mid-Pliocene warm period (mPWP, 3.264 to $3.025 \mathrm{Ma}$ ) is a recent period in earth's history when global temperatures were warmer than modern, but the paleogeography was similar to today (Dowsett et al., 2010). This warm period is thought to have many similarities to the projected warm climate of the late 21 st century, as the global mean temperature is estimated to be $1.84-3.60^{\circ} \mathrm{C}$ warmer than the preindustrial (Haywood et al., 2013). Thus, studying the mPWP is potentially important for understanding warm climate in the near future.

The mPWP has long been a focus for data syntheses (e.g., Dowsett et al., 1994, 1999, 2010; Salzmann et al., 2008) and climate modeling (e.g., Chandler et al., 1994; Jiang et al., 2005; Yan et al., 2011). The US Geological Survey's Pliocene Research Interpretation and Synoptic 
Table 1. Basic information of general circulation models used in this paper.

\begin{tabular}{|c|c|c|c|c|c|}
\hline Model & Type & $\begin{array}{l}\text { Boundary } \\
\text { condition }\end{array}$ & $\begin{array}{l}\text { Atmosphere } \\
\text { resolution }\end{array}$ & $\begin{array}{l}\text { Years for } \\
\text { analyzing }\end{array}$ & References \\
\hline CAM3.1 & AGCM & alternate & $\mathrm{T} 42, \mathrm{~L} 26$ & 30 & Yan et al. (2012b) \\
\hline HadAM3 & AGCM & preferred & $2.5^{\circ} \times 3.75^{\circ}, \mathrm{L} 19$ & 30 & Bragg et al. (2012) \\
\hline LMDZ5A & AGCM & alternate & $1.9^{\circ} \times 3.75^{\circ}, \mathrm{L} 39$ & 30 & Contoux et al. (2012) \\
\hline MIROC4m-AGCM & AGCM & preferred & $\mathrm{T} 42, \mathrm{~L} 20$ & 30 & Chan et al. (2011) \\
\hline MRI-CGCM2.3-AGCM & AGCM & alternate & $\mathrm{T} 42, \mathrm{~L} 30$ & 50 & Kamae and Ueda (2012) \\
\hline CAM4 & AGCM & alternate & T31, L26 & 20 & Zhang and Yan (2012) \\
\hline ECHAM5 & AGCM & preferred & T31, L19 & 30 & Stepanek and Lohmann (2012) \\
\hline ModelE2-R & AOGCM & preferred & $2^{\circ} \times 2.5^{\circ}, \mathrm{L} 40$ & 30 & Chandler et al. (2013) \\
\hline CCSM4 & AOGCM & alternate & $0.9^{\circ} \times 1.25^{\circ}, \mathrm{L} 26$ & 30 & Rosenbloom et al. (2013) \\
\hline HadCM3 & AOGCM & alternate & $2.5^{\circ} \times 3.75^{\circ}, \mathrm{L} 19$ & 50 & Bragg et al. (2012) \\
\hline IPSLCM5A & AOGCM & alternate & $1.9^{\circ} \times 3.75^{\circ}, \mathrm{L} 39$ & 30 & Contoux et al. (2012) \\
\hline MIROC4m & AOGCM & preferred & $\mathrm{T} 42, \mathrm{~L} 20$ & 30 & Chan et al. (2011) \\
\hline MRI-CGCM2.3 & AOGCM & alternate & T42, L30 & 50 & Kamae and Ueda (2012) \\
\hline NorESM-L & AOGCM & alternate & T31, L26 & 100 & Zhang et al. $(2012,2013)$ \\
\hline COSMOS & AOGCM & preferred & T31, L19 & 30 & Stepanek and Lohmann (2012) \\
\hline
\end{tabular}

Mapping (PRISM) project (Dowsett et al., 1994, 1999, 2009, 2010) has studied this period for about $20 \mathrm{yr}$, and the latest PRISM3 dataset has been released recently (Dowsett et al., 2010). Moreover, together with the advancements in midPliocene reconstructions, the mid-Pliocene climate has also been widely simulated with climate models (Chandler et al., 1994; Sloan et al., 1996; Haywood et al., 2000; Haywood and Valdes, 2004; Jiang et al., 2005; Lunt et al., 2010; Yan et al., 2011). Most of these simulations were carried out with atmospheric general circulation models (AGCMs) (Chandler et al., 1994; Sloan et al., 1996; Haywood et al., 2000; Jiang et al., 2005), and only a few were carried out with coupled atmosphere-ocean general circulation models (AOGCMs) (Haywood and Valdes, 2004; Yan et al., 2011). In order to understand further the mPWP climate, the Pliocene Model Intercomparison Project (PlioMIP) was initiated and included in the Paleoclimate Modelling Intercomparison Project (PMIP) phase III. In PlioMIP, two types of experiments were designed (Haywood et al., 2010, 2011). One was performed with AGCMs and the other was performed with AOGCMs. Preliminary results from each model have been published in a special issue in the journal Geoscientific Model Development (see Table 1 for references).

Haywood et al. (2013) presented the first large-scale model-model intercomparison of PlioMIP simulations. They demonstrated that climate models differently interpret the amount of forcing derived from Pliocene boundary conditions, but are able to reproduce many regional changes in temperature reconstructed from geological proxies. Haywood et al. (2013) focused on the model-model intercomparison on a global scale, but paid less attention to regional climate, such as monsoons.

Monsoons are often classified into two groups: tropical monsoons and subtropical monsoons. The tropical monsoons (e.g., Indian monsoon) are mainly driven by the seasonal movement of the intertropical convergence zone (Hoskins and Rodwell, 1995; Chao and Chen, 2001), while the subtropical monsoons (e.g., East Asian monsoon) are further influenced by the land-sea thermal contrast (Ramage, 1971; Webster et al., 1998). Due to the different thermal capacity of land and sea, the cold high-pressure system, which occupies the inland Eurasian continent, drives northwesterlies and northeasterlies over East Asia (East Asian winter winds, EAWWs) during boreal winter (December, January and February, DJF), while the warm low-pressure system drives southwesterlies and southeasterlies (East Asian summer winds, EASWs) and brings precipitation into East Asia during boreal summer (June, July and August, JJA).

In this study, we focus our analysis on the East Asian monsoon climate simulated in China in the PlioMIP models. The investigation of tropical monsoons (e.g., Indian monsoon and African monsoon) will be left for further studies. This paper is organized as follows: in Sect. 2, we present reconstructions of the mid-Pliocene climate in China. In Sect. 3, we briefly describe the models used in the PlioMIP and the experimental design. Then, we evaluate the simulations of preindustrial climate with these models with a focus on China in Sect. 4. In Sect. 5, we analyze the mid-Pliocene climate changes, including $850 \mathrm{hPa}$ wind fields, surface air temperature (SAT) and precipitation, relative to the pre-industrial. Section 6 contains the discussion and summary.

\section{Geological evidence for mid-Pliocene East Asian monsoon}

In China, most mid-Pliocene geological evidence reveals that the EASWs were stronger, and the EAWWs were weaker during the mid-Pliocene, when compared to the late 
Quaternary. Yan et al. (2012a) have summarized these midPliocene proxy records that are well-dated by magnetostratigraphic and/or biostratigraphic chronology. For example, the smaller mean/median grain size and proportion of coarse component (Xiong et al., 2001; Wan et al., 2007; Sun et al., 2008), and the lower content of the 10-70 $\mu \mathrm{m}$ fraction (Jiang and Ding, 2010) in paleosol-loess sediments reveal a weaker aeolian transport by the EAWW, which could indicate either weakened EAWW or wetter climate in the inland China. Since the wetter climate in the inland China is closely related with the weakened EAWW, the weaker aeolian transport indicates the EAWW was weaker during the mid-Pliocene, relative to the late Quaternary. The smaller abundance of planktonic foraminifer Neogloboquadrina dutertrei in South China Sea ocean sediments (Jian et al., 2003; Li et al., 2004a) also supports the weaker EAWW during the mid-Pliocene. In contrast, geochemical indices, including a larger ratio of free iron to total iron concentrations (Ding et al., 2001), a smaller ratio between illite plus chlorite and smectite (Wan et al., 2007), and a larger proportion of finest end-member (fluvial mud) (Wan et al., 2007), indicate increased chemical weathering in China during the mid-Pliocene. The increased chemical weathering reflects a warmer and wetter climate. Since precipitation is brought by the EASW in China, the increased chemical weathering indicates that EASWs are intensified during the warm mid-Pliocene (Ding et al., 2001; Wan et al., 2007).

In addition to the above geological evidence, we collect more proxy data (Table 2) to show temperature and humidity changes between mid-Pliocene and late Quaternary. These proxy data are classified into two groups according to the reliability in chronology and climate interpretation. In the first group, proxy data have a good age control with a small age range between 3.0 and $3.3 \mathrm{Ma}$, and also a relatively reliable climate indication of temperature and/or humidity for the mid-Pliocene (Ma et al., 2005; Wu et al., 2007, 2011; Jiang and Ding, 2008; Cai et al., 2012). In contrast, in the second group, the uncertainties in age control and/or climate interpretation are relatively large. The more reliable reconstructions in the first group, together with the proxy data summarized by Yan et al. (2012a), show that it was warmer and wetter in China during the mid-Pliocene, relative to the late Quaternary (Fig. S1).

In summary, these proxy data demonstrate that it was warmer and wetter in most of China during the mid-Pliocene. The warmer and wetter climate indicates the stronger EASW and the weaker EAWW during the warm mid-Pliocene.

\section{Models and experimental design}

We use the model results from nine climate modeling groups that participated in the PlioMIP. Seven of them provide atmosphere-only simulations for PlioMIP experiment 1 and eight groups provide coupled atmosphere-ocean simulations for PlioMIP experiment 2 (Table 1). All simulations include a pre-industrial experiment and a mid-Pliocene experiment. Compared to the pre-industrial experiment, the changes of boundary conditions in the mid-Pliocene experiment include the modification in topography (Sohl et al., 2009), land cover (Salzmann et al., 2008) and the increase of atmospheric $\mathrm{CO}_{2}$ concentration to $405 \mathrm{ppmv}$. The mPWP topography increases in most areas of monsoon China, the Tarim Basin and the southern margin of the Tibetan Plateau, but decreases in most areas of the Tibetan Plateau, compared to the pre-industrial topography (Fig. 1). The mPWP vegetation indicates a generally warmer and wetter climate than today, and warmtemperate forests become dominant in East Asia in the midPliocene (Salzmann et al., 2008). Models generally use the same mPWP vegetation dataset, but the vegetation data used in pre-industrial experiments are independent. Atmosphereonly simulations are forced with the fixed mid-Pliocene sea surface temperature (SST) (Dowsett et al., 2009; Robinson et al., 2011). Due to the complexity in modification of land-sea mask in mid-Pliocene experiment, nine simulations choose the alternate boundary condition with the land-sea mask being identical to the pre-industrial (Table 1). Further details of boundary conditions and experimental design for the PlioMIP can be found in Haywood et al. (2010, 2011).

\section{Evaluation of the models}

In order to know the model abilities in simulating the East Asian monsoon climate, we evaluate the simulated winds, SAT and precipitation in the pre-industrial experiments, with comparisons to the NCEP-DOE reanalysis data during the period 1979-2008 (Kanamitsu et al., 2002), the ERA40 monthly reanalysis data during the period 1972-2001 (Uppala et al., 2005) and the CMAP precipitation data during the period 1979-2008 (Xie and Arkin, 1996), respectively. Although a bias exists in the evaluation due to the warmer modern climate than the pre-industrial, evaluation of preindustrial simulations is often based on modern observations, since the observed pre-industrial SAT and precipitation data are not available.

We regrid all model results and observations to the resolution of $2.5^{\circ} \times 2.5^{\circ}$ (Fig. S2), and then calculate spatial correlation coefficients (SCCs) and root-mean-square errors (RMSEs) excluding systematic model error. The SCCs quantify similarities between simulated and observed spatial patterns. Larger correlations indicate higher similarities. The RMSEs assess internal model errors. Larger root-mean-square values indicate larger internal model errors. Additionally, the systematic model errors are also analyzed for the meridional wind at $850 \mathrm{hPa}$ (Table S1).

The SCC and RMSE of meridional wind at $850 \mathrm{hPa}$ in the East Asian region (between $20-45^{\circ} \mathrm{N}$ and $105-135^{\circ} \mathrm{E}$ ) show that the models used in the PlioMIP have a wide range of skills in simulating East Asian monsoon climate. The 
Table 2. Data used to reconstruct the mid-Pliocene climate in China.

\begin{tabular}{|c|c|c|c|c|c|c|c|c|}
\hline No. & Site & Proxy data & Dating & Location & $\begin{array}{l}\text { Age } \\
\text { (Ma) }\end{array}$ & $\begin{array}{l}\text { Geological records (compared to } \\
\text { the late Quaternary) }\end{array}$ & $\begin{array}{l}\text { Reconstructed } \\
\text { climate }\end{array}$ & References \\
\hline \multicolumn{9}{|c|}{ First group } \\
\hline 1 & $\begin{array}{l}\text { Sikouzi, } \\
\text { Gansu }\end{array}$ & Pollen & $\begin{array}{l}\text { Paleomagnetism, } \\
\text { biostratigraphy }\end{array}$ & $\begin{array}{l}36^{\circ} 16^{\prime} \mathrm{N} \\
105^{\circ} 59^{\prime} \mathrm{E}\end{array}$ & $3.3-3.0$ & More tree and shrubs, fewer herbs & Wetter & $\begin{array}{l}\text { Jiang and Ding } \\
(2008)\end{array}$ \\
\hline 2 & $\begin{array}{l}\text { Chaona, } \\
\text { Gansu }\end{array}$ & Pollen & Paleomagnetism & $\begin{array}{l}35^{\circ} 7^{\prime} \mathrm{N} \\
107^{\circ} 12^{\prime} \mathrm{E}\end{array}$ & $3.0-2.6$ & $\begin{array}{l}\text { A domination of typical Cupressaceae } \\
\text { forest vegetation }\end{array}$ & Warmer and wetter & Wu et al. (2007) \\
\hline 3 & $\begin{array}{l}\text { Qaidam } \\
\text { Basin }\end{array}$ & Pollen & Paleomagnetism & $\begin{array}{l}38^{\circ} 22^{\prime} \mathrm{N} \\
91^{\circ} 44^{\prime} \mathrm{E}\end{array}$ & $3.1-3.0$ & $\begin{array}{l}\text { Higher abundance of broad-leaved trees } \\
\text { and lower abundance of xerophytic taxa }\end{array}$ & Warmer and wetter & Cai et al. (2012) \\
\hline 4 & $\begin{array}{l}\text { Qaidam } \\
\text { Basin }\end{array}$ & Pollen & $\begin{array}{l}\text { Paleomagnetism } \\
\text { biostratigraphy }\end{array}$ & $\begin{array}{l}\sim 37.8^{\circ} \mathrm{N} \\
\sim 94.8^{\circ} \mathrm{E}\end{array}$ & $3.3-3.0$ & $\begin{array}{l}\text { Low fraction of xerophytic plants and } \\
\text { the existence of thermophilous subtrop- } \\
\text { ical trees }\end{array}$ & Warmer and wetter & Wu et al. (2011) \\
\hline \multicolumn{9}{|c|}{ Second group } \\
\hline 6 & $\begin{array}{l}\text { Yushe, } \\
\text { Shanxi }\end{array}$ & $\begin{array}{l}\text { Fruits, } \\
\text { seeds }\end{array}$ & Paleomagnetism & $\begin{array}{l}36^{\circ} 58^{\prime} \mathrm{N} \\
112^{\circ} 50^{\prime} \mathrm{E}\end{array}$ & $3.5-2.3$ & The existence of lake and Ruppia & Wetter & Zhao et al. (2004) \\
\hline 7 & $\begin{array}{l}\text { Taigu } \\
\text { and } \\
\text { Yushe, } \\
\text { Shanxi }\end{array}$ & Pollen & Paleomagnetism & $\begin{array}{l}\sim 37.5^{\circ} \mathrm{N} \\
\sim 114^{\circ} \mathrm{E}\end{array}$ & $3.6-2.5$ & $\begin{array}{l}\text { The high percentages of Picea and } \\
\text { Abies, and the absence of thermophiles } \\
\text { in pollen assemblages }\end{array}$ & Colder and wetter & Li et al. (2004b) \\
\hline 8 & $\begin{array}{l}\text { Shijiawan, } \\
\text { Shaanxi }\end{array}$ & Pollen & Paleomagnetism & $\begin{array}{l}\sim 34.4^{\circ} \mathrm{N} \\
\sim 109.7^{\circ} \mathrm{E}\end{array}$ & $3.0-2.7$ & $\begin{array}{l}\text { Typical steppe type; with elephant fos- } \\
\text { sil fauna }\end{array}$ & Warmer and drier & Han et al. (1997) \\
\hline 9 & $\begin{array}{l}\text { Xifeng, } \\
\text { Gansu }\end{array}$ & Molluscan & Paleomagnetism & $\begin{array}{l}35^{\circ} 53^{\prime} \mathrm{N} \\
107^{\circ} 58^{\prime} \mathrm{E}\end{array}$ & $3.4-2.4$ & $\begin{array}{l}\text { Increase of cold-aridiphilous taxa, de- } \\
\text { crease of meso-xerophilous and the rare } \\
\text { occurrence of thermo-humidiphilous } \\
\text { mollusks }\end{array}$ & Colder and drier & Wu et al. (2006) \\
\hline 11 & $\begin{array}{l}\text { Eastern } \\
\text { China }\end{array}$ & $\begin{array}{l}\text { Fossil } \\
\text { mammals }\end{array}$ & Stratigraphy & $\begin{array}{l}32^{\circ} \mathrm{N} \\
105^{\circ} \mathrm{E}^{*}\end{array}$ & $3.4-2.0$ & High hypsodonty & Drier & Eronen et al. (2010) \\
\hline 12 & $\begin{array}{l}\text { Yuanmou, } \\
\text { Yunnan }\end{array}$ & $\begin{array}{l}\text { Fossil } \\
\text { wood, } \\
\text { leaves, } \\
\text { pollen }\end{array}$ & $\begin{array}{l}\text { Paleomagnetism, } \\
\text { biostratigraphy, } \\
\text { lithostratigraphy }\end{array}$ & $\begin{array}{l}\sim 25.7^{\circ} \mathrm{N} \\
\sim 101.9^{\circ} \mathrm{E}\end{array}$ & $3.4-2.5$ & Based on coexistence approach & Colder and wetter & Yao et al. (2012) \\
\hline 13 & $\begin{array}{l}\text { Tuantian, } \\
\text { Yunnan }\end{array}$ & $\begin{array}{l}\text { Fossil } \\
\text { leaves }\end{array}$ & Stratigraphy & $\begin{array}{l}24^{\circ} 41^{\prime} \mathrm{N} \\
98^{\circ} 37^{\prime} \mathrm{E}\end{array}$ & $3.3-2.3$ & $\begin{array}{l}\text { Based on leaf margin analysis and } \\
\text { the Climate Leaf Analysis Multivariate } \\
\text { Program }\end{array}$ & Warmer and drier & Xie et al. (2012) \\
\hline 14 & $\begin{array}{l}\text { Tengchong } \\
\text { Yunnan }\end{array}$ & $\begin{array}{r}\text { gFossil } \\
\text { plants }\end{array}$ & $\begin{array}{l}\text { Biostratigraphy, } \\
\text { isotopic dating }\end{array}$ & $\begin{array}{l}\sim 24.7^{\circ} \mathrm{N} \\
\sim 98.4^{\circ} \mathrm{E}\end{array}$ & $\begin{array}{l}\text { Late } \\
\text { Pliocene }\end{array}$ & Based on coexistence approach & Warmer & Sun et al. (2011) \\
\hline 15 & $\begin{array}{l}\text { Eryuan, } \\
\text { Yunnan }\end{array}$ & Pollen & $\begin{array}{l}\text { Biostratigraphy, } \\
\text { lithostratigra- } \\
\text { phy }\end{array}$ & $\begin{array}{l}26^{\circ} 00^{\prime} \mathrm{N} \\
99^{\circ} 49^{\prime} \mathrm{E}\end{array}$ & $\begin{array}{l}\text { Late } \\
\text { Pliocene }\end{array}$ & Based on coexistence approach & Warmer & Kou et al. (2006) \\
\hline 16 & $\begin{array}{l}\text { Yangyi, } \\
\text { Yunnan }\end{array}$ & Pollen & Stratigraphy & $\begin{array}{l}24^{\circ} 57^{\prime} \mathrm{N} \\
99^{\circ} 15^{\prime} \mathrm{E}\end{array}$ & $\begin{array}{l}\text { Late } \\
\text { Pliocene }\end{array}$ & Based on coexistence approach & Warmer and wetter & Kou et al. (2006) \\
\hline 17 & $\begin{array}{l}\text { Longling, } \\
\text { Yunnan }\end{array}$ & Pollen & Stratigraphy & $\begin{array}{l}24^{\circ} 41^{\prime} \mathrm{N} \\
98^{\circ} 50^{\prime} \mathrm{E}\end{array}$ & $\begin{array}{l}\text { Late } \\
\text { Pliocene }\end{array}$ & Based on coexistence approach & Warmer and drier & Kou et al. (2006) \\
\hline 18 & $\begin{array}{l}\text { Zhangqiu, } \\
\text { Shan- } \\
\text { dong }\end{array}$ & Pollen & Biostratigraphy & $\begin{array}{l}36^{\circ} 43^{\prime} \mathrm{N} \\
117^{\circ} 27^{\prime} \mathrm{E}\end{array}$ & Pliocene & $\begin{array}{l}\text { The distribution of a few subtropical } \\
\text { and warm temperate broadleaf trees }\end{array}$ & Warmer and wetter & Wang et al. (2002) \\
\hline 19 & $\begin{array}{l}\text { Lop } \\
\text { Nur, } \\
\text { Xin- } \\
\text { jiang }\end{array}$ & Pollen & Paleomagnetism & $\begin{array}{l}39^{\circ} 47^{\prime} \mathrm{N} \\
88^{\circ} 23^{\prime} \mathrm{E}\end{array}$ & Pliocene & Based on coexistence approach & Warmer and wetter & Hao et al. (2012) \\
\hline
\end{tabular}

* Only taken at one point $\left(32^{\circ} \mathrm{N}, 105^{\circ} \mathrm{E}\right)$. 


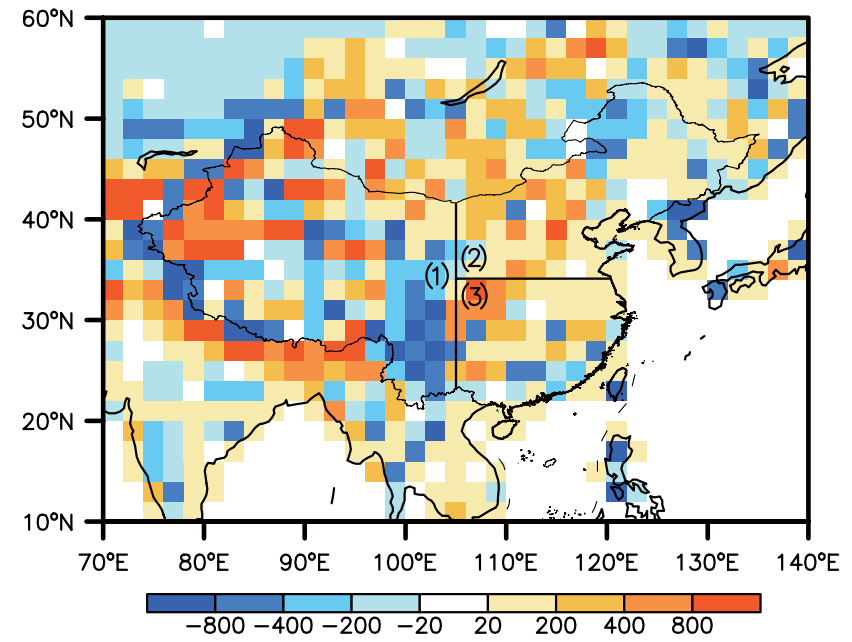

Fig. 1. Topography differences (units: $m$ ) between mid-Pliocene and pre-industrial experiments provided by PRISM3. Regions (1), (2) and (3) represent western China, north monsoon China and south monsoon China, respectively. Regions (2) and (3) together represent monsoon China.

correlations of EAWW are generally larger than the correlations of EASW, indicating that models have better skills in simulating the winter winds than the summer winds. For the EASW (Table S1), there are four models that show negative correlations or confidence levels of correlation lower than $95 \%$. Moreover, most models simulate smaller systematic model errors than the RMSE (Table S1).

The above model ability in simulating the East Asian monsoon climate is also supported by Taylor diagrams (Taylor, 2001) for meridional wind at $850 \mathrm{hPa}$ (Fig. 2). The points of simulated winter winds show less scatter around the reference point than the points of simulated summer winds, indicating that the simulations of winter winds are better than those of summer winds. For the EASW (EAWW), the best model is ModelE2-R (HadAM3). The point on the Taylor diagram (Fig. 2) representing the multi-model ensemble mean (MMM) shows a better skill than most individual models in simulating the summer and winter winds.

The PlioMIP models have different skills (Table S2) in simulating the pre-industrial annual and seasonal SAT and precipitation over China. Compared to the observations, correlations for annual and seasonal SAT exceed 0.85 in these pre-industrial simulations, indicating these models can reasonably simulate SAT over China. The best model is HadAM3 for annual SAT. In contrast, the range of model abilities is large in simulating the annual or seasonal precipitation over China. The best one remains HadAM3 for annual precipitation.

In the Taylor diagrams (Fig. 3), the points of simulated SAT gather closely to the reference point. In contrast, the points of simulated precipitation scatter and are far away from the reference point, indicating a larger model-model discrepancy in simulating precipitation over China. Moreover, the MMM point is close to the reference point, not only for SAT but also for precipitation, indicating the MMM is better than most individual models in simulating SAT and precipitation over China.

\section{Model-model intercomparison}

\subsection{Mid-Pliocene East Asian monsoon}

Here, we use a classic index, regionally averaged meridional wind speeds at $850 \mathrm{hPa}$ (Wu and Ni, 1997; Wang et al., 2001; Jiang and Lang, 2010) within the region of $20-45^{\circ} \mathrm{N}$ and $105-135^{\circ} \mathrm{E}$ to indicate the intensity of East Asian summer and winter winds. A positive index represents southerly wind anomalies, thus indicating intensified EASW or weakened EAWW, while a negative index represents northerly wind anomalies, thus indicating weakened EASW or intensified EAWW.

Within the PlioMIP ensemble, the MMM index of all models shows that the simulated mid-Pliocene EASWs become stronger, and EAWWs become slightly stronger, relative to the pre-industrial. In boreal summer, the mid-Pliocene MMM index is $0.65 \mathrm{~m} \mathrm{~s}^{-1}$ higher, and southwesterly anomalies (enhanced EASW) appear in monsoon China (Fig. 4a, Table 3). In boreal winter, the mid-Pliocene MMM index is $0.06 \mathrm{~m} \mathrm{~s}^{-1}$ lower than the pre-industrial. Northeasterly anomalies (enhanced EAWW) appear in south monsoon China, while weak southeasterly anomalies (weakened EAWW) occur in north monsoon China (Fig. 4b, Table 3).

The multi-model ensemble mean of coupled models (AOGCMs-MMM) shows less strengthening in the midPliocene EASW (Fig. 5c vs. Fig. 5a), and further weakening in the mid-Pliocene EAWW in north monsoon China (Fig. 5d vs. Fig. 5b), relative to the multi-model ensemble mean of atmosphere-only models (AGCMs-MMM). For individual models, 14 simulations show increased indices for the EASW, ranging from $0.12 \mathrm{~m} \mathrm{~s}^{-1}$ (CCSM4) to $1.32 \mathrm{~m} \mathrm{~s}^{-1}$ (HadAM3), while only COSMOS simulates a decreased index of $0.30 \mathrm{~m} \mathrm{~s}^{-1}$ (Table 3, Fig. S3). In contrast, the modelmodel discrepancy is much larger in simulating the midPliocene winter winds (Table 3, Fig. S4). The indices of EAWW decrease (indicating strengthened EAWW) in 9 simulations, but increase (indicating weakened EAWW) in the other 6 simulations (namely CAM4, MIROC4m-AGCM, NorESM-L, MIROC4m, HadCM3 and ModelE2-R).

As suggested by the reconstructions of the mid-Pliocene East Asian monsoon (see Sect. 2), if only the six models that simulate the weakened winter winds are considered, the obvious southeasterly anomalies occur in monsoon China in boreal winter (Fig. 4d). Moreover, these six models also show that the mid-Pliocene summer winds are further strengthened (Fig. 4c vs. Fig. 4a), when compared to the MMM of all models. 

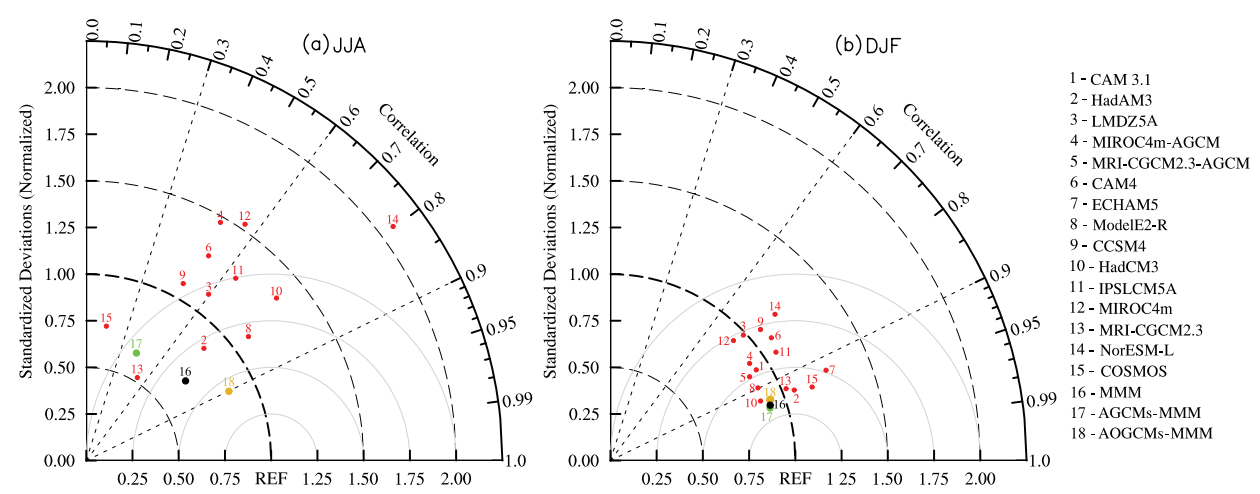

Fig. 2. Taylor diagrams of (a) summer and (b) winter meridional wind at $850 \mathrm{hPa}$ in the East Asian regions of $20-45^{\circ} \mathrm{N}$ and $105-135^{\circ} \mathrm{E}$ for different models. The point REF indicates the NCEP-DOE reanalysis data averaged within 1979-2008 (Kanamitsu et al., 2002). The model results (CAM3.1, MRI-CGCM2.3-AGCM and ECHAM5) with negative SCC in (a) are not shown. In the Taylor diagram, the standard deviation of the modeled field is the radial distance from the origin. The RMSE is the distance to the point REF. The azimuthal position gives the SCC. The RMSE and the modeled standard deviation are normalized by the observed standard deviation.
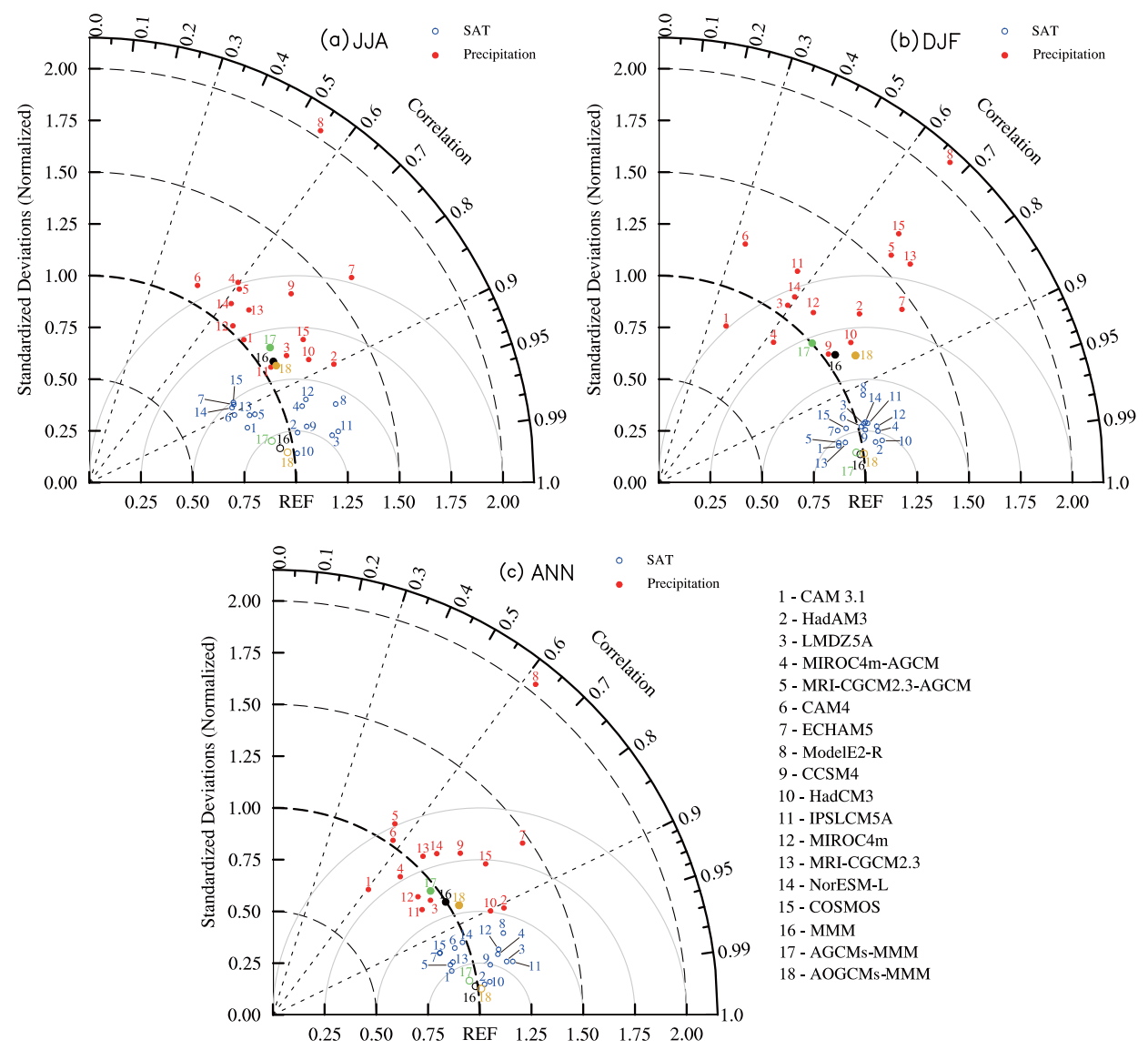

1 - CAM 3.1
2 - HadAM3

2 - HadAM3

4 - MIROC4m-AGCM

5 - MRI-CGCM2.3-AGCM

6 - CAM4

7 - ECHAM5
8 - ModelE2-R

8 - ModelE2-R
9 - CCSM4

10 - HadCM3

11 - IPSLCM5A

13 - MRI-CGCM2

14 - NorESM-L

14 - NorESM-
15 COSMOS

16 - MMM

17 - AGCMs-MMM

18 - AOGCMs-MMM

Fig. 3. Taylor diagrams of (a) summer, (b) winter and (c) annual mean SAT and precipitation in China for different models. The point REF indicates the ERA40 reanalysis data averaged within 1972-2001 (Uppala et al., 2005) for SAT, and the CMAP data averaged within 1979-2008 (Xie and Arkin, 1996) for precipitation. 

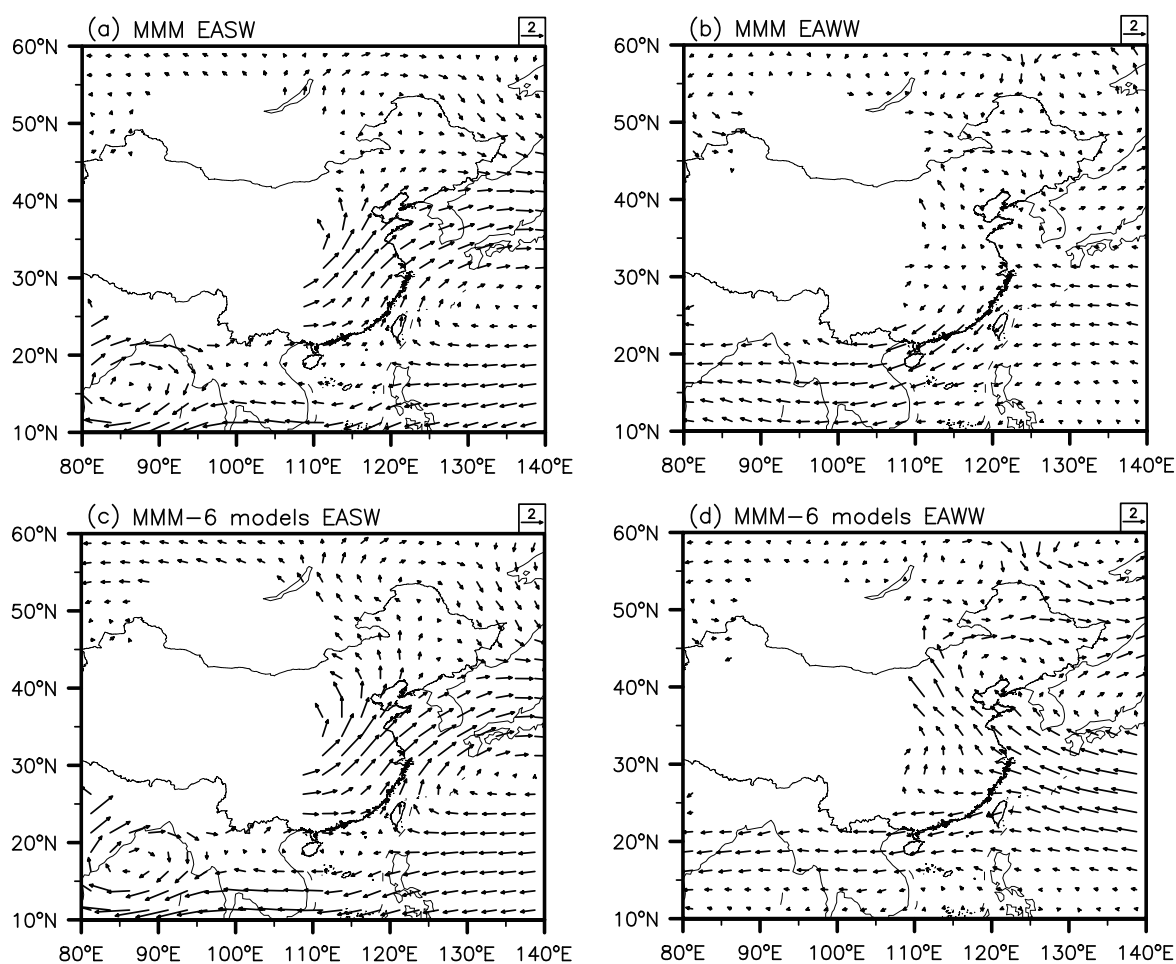

Fig. 4. The MMM for EASW (left column, units: $\mathrm{m} \mathrm{s}^{-1}$ ) and EAWW differences (right column, units: $\mathrm{m} \mathrm{s}^{-1}$ ) between mid-Pliocene and pre-industrial experiments. (a) and (b) are the MMM of all models; (c) and (d) are the MMM of the six models that simulate the weakened EAWW listed in Table 3. Regions with an elevation above $1500 \mathrm{~m}$ are left blank.
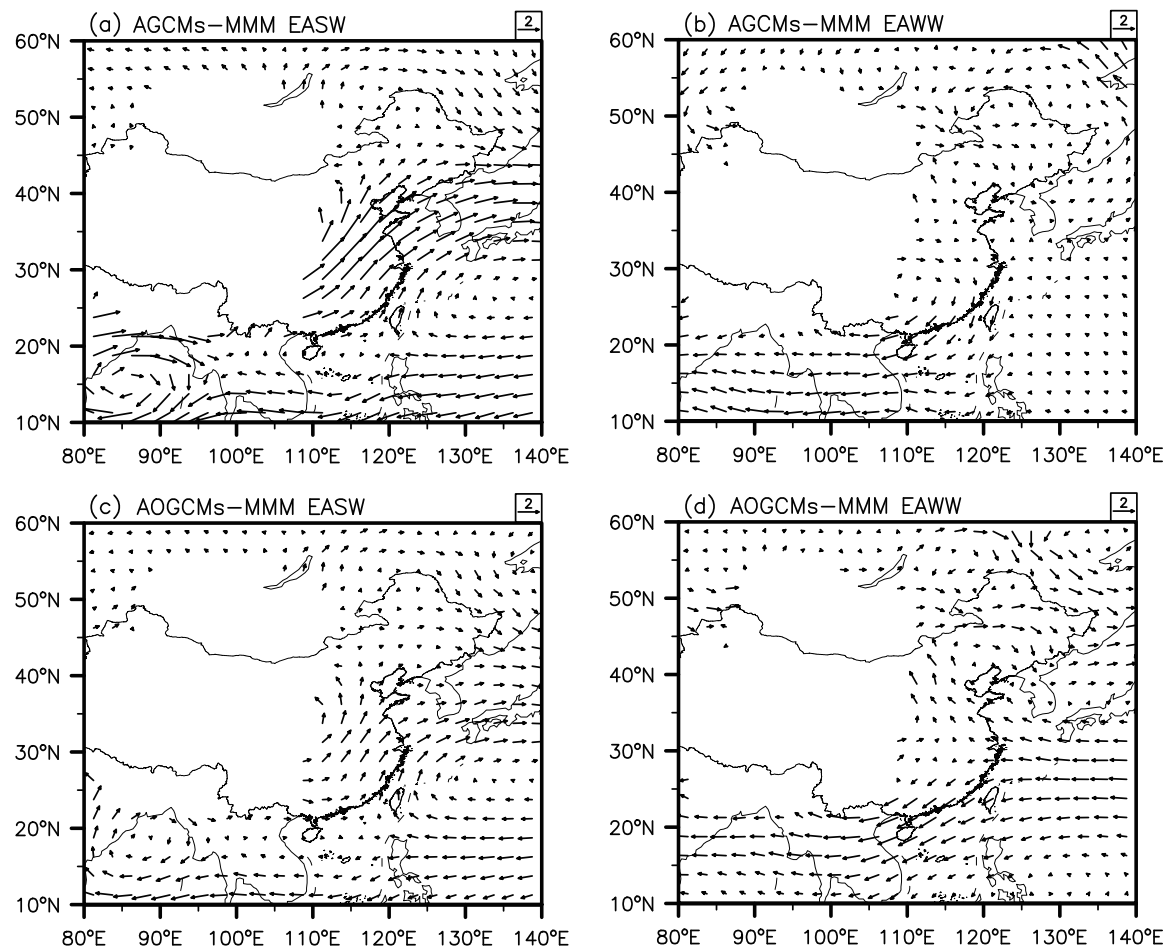

Fig. 5. The MMM for EASW (left column, units: $\mathrm{m} \mathrm{s}^{-1}$ ) and EAWW differences (right column, units: $\mathrm{m} \mathrm{s}^{-1}$ ) between mid-Pliocene and pre-industrial experiments. (a) and (b) are the AGCMs-MMM; (c) and (d) are the AOGCMs-MMM. Regions with an elevation above $1500 \mathrm{~m}$ are left blank. 
Table 3. The regionally averaged changes of EAWW, EASW, SAT and precipitation between mid-Pliocene and pre-industrial experiments. The EAWW and EASW indices (units: $\mathrm{m} \mathrm{s}^{-1}$ ) are calculated by regionally averaged meridional wind speed at $850 \mathrm{hPa}$ within the region of $20-45^{\circ} \mathrm{N}$ and $105-135^{\circ} \mathrm{E}$. The SAT (units: ${ }^{\circ} \mathrm{C}$ ) and precipitation (units: mm day ${ }^{-1}$ ) changes are calculated by regionally averaged values within China.

\begin{tabular}{|c|c|c|c|c|c|c|c|c|c|c|}
\hline \multirow[t]{2}{*}{ Model } & \multicolumn{2}{|c|}{ EASW } & \multicolumn{2}{|c|}{ EAWW } & \multicolumn{3}{|c|}{ SAT changes } & \multicolumn{3}{|c|}{ Precipitation changes } \\
\hline & Pre-industrial & Changes & Pre-industrial & Changes & ANN & JJA & DJF & ANN & JJA & DJF \\
\hline CAM3.1 & 2.60 & 0.58 & -2.24 & -0.20 & 1.50 & 1.48 & 1.54 & 0.17 & -0.09 & 0.02 \\
\hline HadAM3 & 3.01 & 1.32 & -1.98 & -0.30 & 1.84 & 1.35 & 2.16 & 0.45 & 0.50 & 0.12 \\
\hline LMDZ5A & 1.99 & 0.82 & -2.51 & -0.37 & 2.05 & 2.12 & 1.79 & 0.18 & 0.37 & -0.01 \\
\hline MIROC4m-AGCM & 3.57 & 0.99 & -1.42 & 0.02 & 2.97 & 1.57 & 4.10 & 0.52 & 0.42 & 0.13 \\
\hline MRI-CGCM2.3-AGCM & 1.10 & 1.27 & 0.29 & -0.22 & 2.04 & 0.91 & 3.33 & 0.27 & 0.36 & -0.12 \\
\hline CAM4 & 2.88 & 0.77 & -3.71 & 0.67 & 2.70 & 1.68 & 3.66 & 0.27 & 0.07 & 0.04 \\
\hline ECHAM5 & 2.97 & 0.56 & -1.46 & -0.45 & 2.05 & 1.41 & 3.11 & -0.10 & -0.73 & -0.08 \\
\hline ModelE2-R & 0.77 & 0.43 & -1.55 & 0.28 & 1.46 & 2.86 & 0.37 & 0.17 & 0.71 & -0.15 \\
\hline CCSM4 & 2.99 & 0.12 & -2.44 & -0.09 & 2.24 & 1.92 & 2.60 & 0.20 & 0.05 & 0.25 \\
\hline HadCM3 & 2.48 & 1.20 & -2.21 & 0.84 & 4.49 & 4.17 & 5.45 & 0.75 & 0.83 & 0.37 \\
\hline IPSLCM5A & 1.59 & 0.22 & -2.38 & -0.36 & 2.28 & 2.22 & 2.18 & 0.24 & 0.47 & 0.07 \\
\hline MIROC4m & 3.57 & 1.07 & -2.65 & 0.94 & 4.08 & 3.37 & 4.66 & 0.63 & 0.47 & 0.31 \\
\hline MRI-CGCM2.3 & 2.39 & 0.36 & -0.09 & -0.33 & 2.06 & 1.33 & 2.99 & 0.20 & 0.24 & -0.02 \\
\hline NorESM-L & 3.71 & 0.31 & -3.38 & 0.17 & 3.43 & 2.32 & 4.50 & 0.33 & 0.24 & 0.12 \\
\hline COSMOS & 2.75 & -0.30 & -0.93 & -1.53 & 4.34 & 4.08 & 4.91 & -0.51 & -0.77 & -0.33 \\
\hline MMM & & 0.65 & & -0.06 & 2.64 & 2.18 & 3.16 & 0.25 & 0.21 & 0.05 \\
\hline AGCMs-MMM & & 0.90 & & -0.12 & 2.17 & 1.50 & 2.81 & 0.25 & 0.13 & 0.01 \\
\hline AOGCMs-MMM & & 0.43 & & 0.00 & 3.05 & 2.78 & 3.46 & 0.25 & 0.28 & 0.08 \\
\hline
\end{tabular}

\subsection{SAT}

The MMM annual SAT averaged over China increases by $2.64{ }^{\circ} \mathrm{C}$ in the mid-Pliocene experiments compared to the pre-industrial (Table 3). Stronger warming appears in western China. Regionally averaged SAT increases by $3.08^{\circ} \mathrm{C}$ in western China and by $2.19^{\circ} \mathrm{C}$ in monsoon China. In addition to the warming, small cooling areas appear in the Tarim Basin and the southern margin of Tibetan Plateau (Fig. 6a). These changes in SAT are closely related to the regional topography changes (Fig. 1). The increased regional topography is in favor of decreased SAT, and vice versa.

The changes in AGCMs-MMM or AOGCMs-MMM annual SAT are similar to the MMM of all models over China, although the warming amplitude simulated with coupled models is slightly larger than atmosphere-only models (Fig. 7c vs. Fig. 7a). The mid-Pliocene AOGCMs-MMM annual SAT regionally averaged over China is $3.05^{\circ} \mathrm{C}$ higher than the pre-industrial. It is $0.88^{\circ} \mathrm{C}$ greater than the SAT increase in the AGCMs-MMM.

For individual models, all models simulate warmer climates over China in the mid-Pliocene experiments, relative to the pre-industrial (Table 3, Fig. S5). The increases of annual SAT regionally averaged over China range from $1.46^{\circ} \mathrm{C}$ (ModelE2-R) to $4.49^{\circ} \mathrm{C}$ (HadCM3). Smaller scale changes in annual SAT in China are also captured by simulations, in particular the simulations with higher resolution models (Fig. S5).
The six models that produce the weakened EAWW generally simulate stronger mid-Pliocene warming over China than other models (Fig. 6c vs. Fig. 6a), particularly in boreal winter (Fig. 8c vs. Fig. 8a). As a result, a further decreased land-sea thermal contrast in boreal winter, which causes the weakened EAWW, appears in the mid-Pliocene experiments simulated with these six models, when compared to other models (Fig. 9b).

\subsection{Precipitation}

The mid-Pliocene MMM annual precipitation averaged over China increases by $0.25 \mathrm{~mm} \mathrm{day}^{-1}$, relative to the preindustrial. The annual MMM precipitation increases in most areas of China. However, decreased precipitation also can be observed in some small areas, for example in south monsoon China and the southern margin of the Tibetan Plateau (Fig. 6b). The simulated changes in precipitation show similar patterns between coupled and atmosphere-only models over China (Fig. 7d vs. Fig. 7b). For individual models, the changes in annual precipitation averaged over China range from $-0.51 \mathrm{~mm} \mathrm{day}^{-1}$ to $0.75 \mathrm{~mm} \mathrm{day}^{-1}$, and only ECHAM5 and COSMOS simulate decreased annual precipitation. Although the changes in annual precipitation simulated with most models generally agree with the changes in MMM, individual simulations still show considerable differences in spatial distribution (Fig. S7).

These six models that simulate the weakened EAWW show a larger increase of annual precipitation in monsoon 

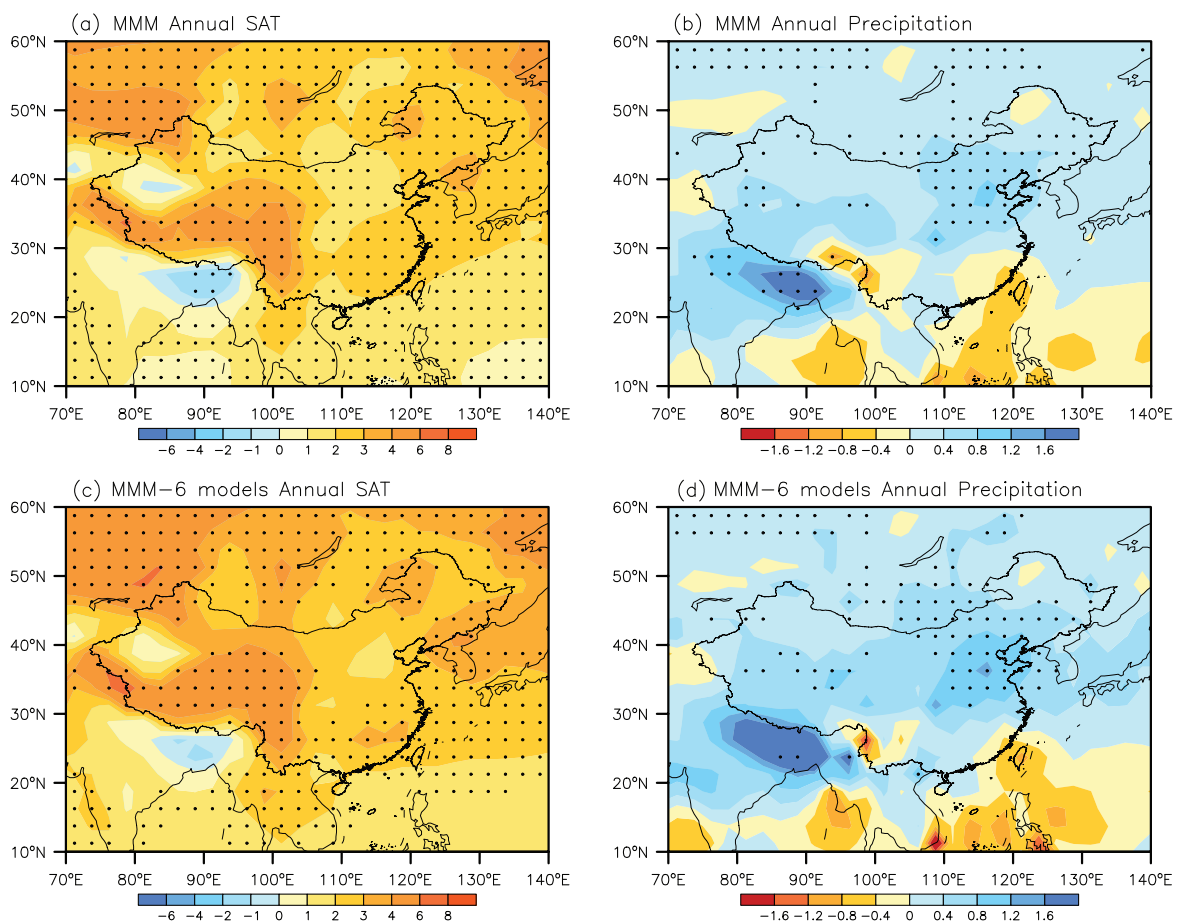

Fig. 6. Same as Fig. 4, but for annual mean SAT (left column, units: ${ }^{\circ} \mathrm{C}$ ) and precipitation differences (right column, units: mm day ${ }^{-1}$ ). The areas with confidence levels larger than $95 \%$ using Student's $t$ test are dotted. The standard deviation of the simulated annual SAT and precipitation changes can be seen in Fig. S6.

(a) AGCMs-MMM Annual SAT

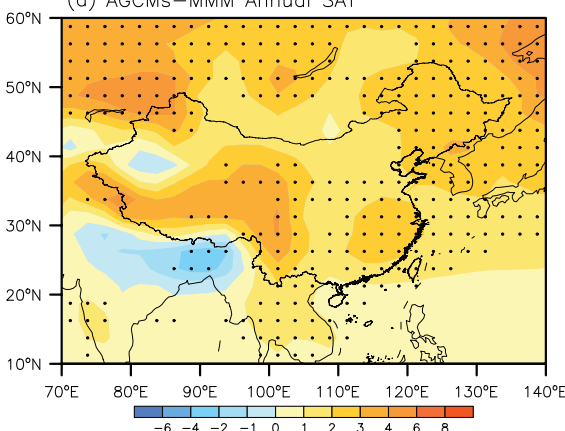

(c) AOGCMs-MMM Annual SAT

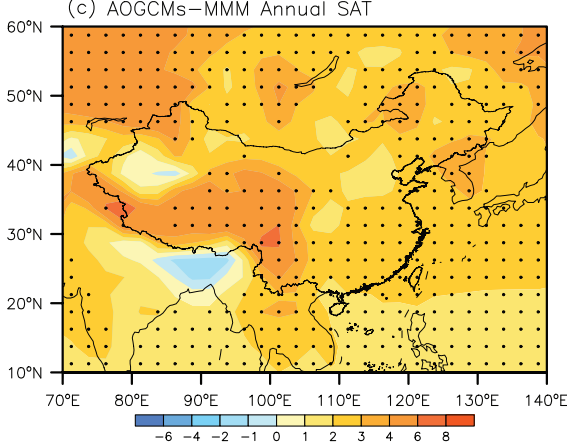

(b) AGCMs-MMM Annual Precipitation

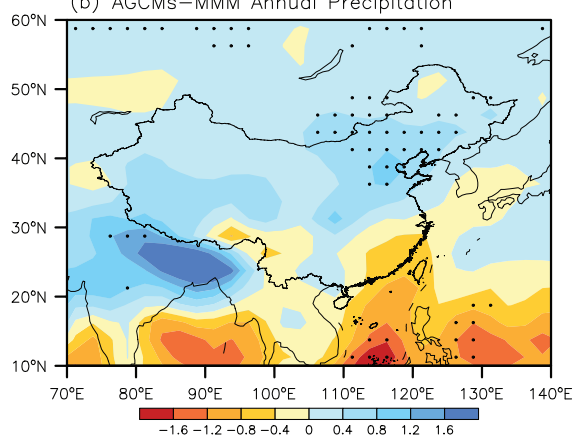

(d) AOGCMs-MMM Annual Precipitation

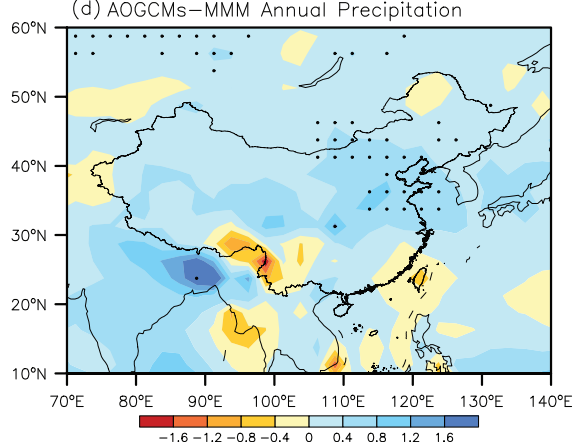

Fig. 7. Same as Fig. 5, but for annual mean SAT (left column, units: ${ }^{\circ} \mathrm{C}$ ) and precipitation differences (right column, units: mm day ${ }^{-1}$ ). The areas with confidence levels larger than $95 \%$ using Student's $t$ test are dotted. 

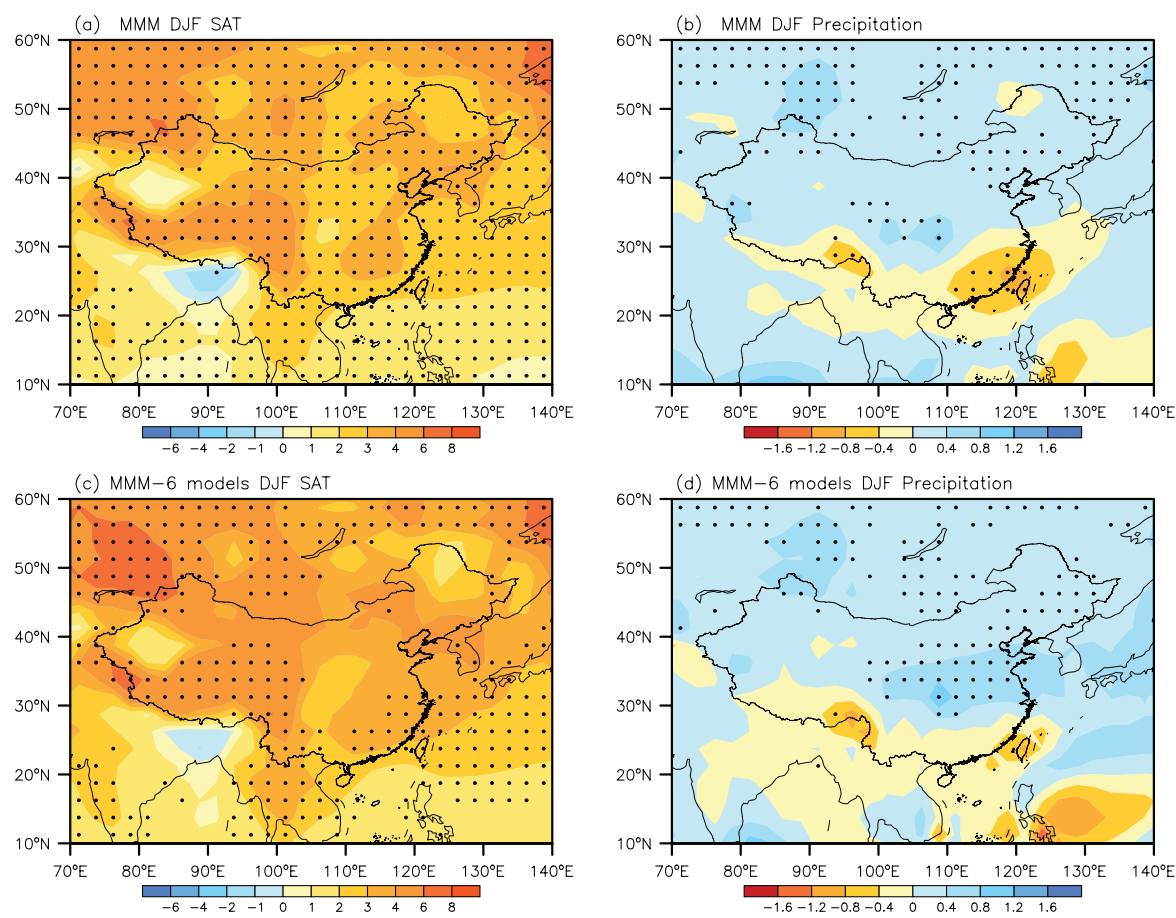

Fig. 8. Same as Fig. 6, but for winter SAT (left column, units: ${ }^{\circ} \mathrm{C}$ ) and precipitation differences (right column, units: $\mathrm{mm} \mathrm{day}^{-1}$ ).

China than the MMM of all models (Fig. 6d vs. Fig.6b). The larger increases in annual precipitation are consistent with the further intensified EASW and weakened EAWW simulated by these six models (Fig. $4 \mathrm{c}$ and d).

\section{Discussion and summary}

The above model-model intercomparisons show that, in the MMM of all models, the simulated mid-Pliocene EASWs largely strengthen in monsoon China, and EAWWs strengthen in south monsoon China, but slightly weaken in north monsoon China (Fig. 4a and b), relative to the preindustrial. Moreover, the MMM shows a warmer and wetter mid-Pliocene climate in most areas of China, which agrees with most of reconstructed data (Fig. S1).

Coupled models generally show less strengthening in the summer winds than atmosphere-only models, as well as enhanced weakening in winter winds in north monsoon China. In the mid-Pliocene simulations with atmosphere-only models, warming in ocean surface is fixed to the PRISM3 reconstructions. However, with coupled models, the simulated warming at the Pacific surface in boreal summer is stronger in the experiments than the PRISM3 reconstructions (Fig. 9a). The simulated stronger ocean surface warming reduces the land-sea thermal contrast and thus limits the intensification of EASW in coupled models, when compared to atmosphere-only simulations. In boreal winter, the stronger surface warming in coupled models, in particular over China, reduces the land-sea thermal contrast, and thus leads to the further weakened EAWW in north monsoon China, when compared to the atmosphere-only simulations (Fig. 9b).

Although most models simulate the intensified EASW, the inter-model discrepancy in simulating the mid-Pliocene EAWW can not be neglected. Nine models produce intensified winter wind indices, yet six models produce weakened winter wind indices (Table 3). These six models show larger decreases in sea level pressure (SLP) gradient and stronger weakened land-sea thermal contrast (averaged within the region of $10-40^{\circ} \mathrm{N}$ and $90-180^{\circ} \mathrm{E}$, Fig. 10) in boreal winter, which causes the weakened EAWW in the mid-Pliocene experiments. The further weakened land-sea thermal contrast is clearly a result of stronger winter warming over China. As shown in Fig. 9b, in boreal winter, the warming over China in these six models is much larger than the MMM of all models, while the ocean warming is similar. Compared to the midPliocene monsoon reconstructions, the simulated weakened mid-Pliocene winter winds in north monsoon China and intensified summer winds in monsoon China agree with geological evidence (Ge et al., 2013). The weakened winter winds reduce the dry airflow from inland Asia. Due to the weakened winter winds together with wetter climate in the mid-Pliocene, the dust from arid inland Asia should have been reduced in the mid-Pliocene. As a result, dust accumulation rate was low on the Loess Plateau in the mid-Pliocene relative to the present (Guo et al., 2002). 

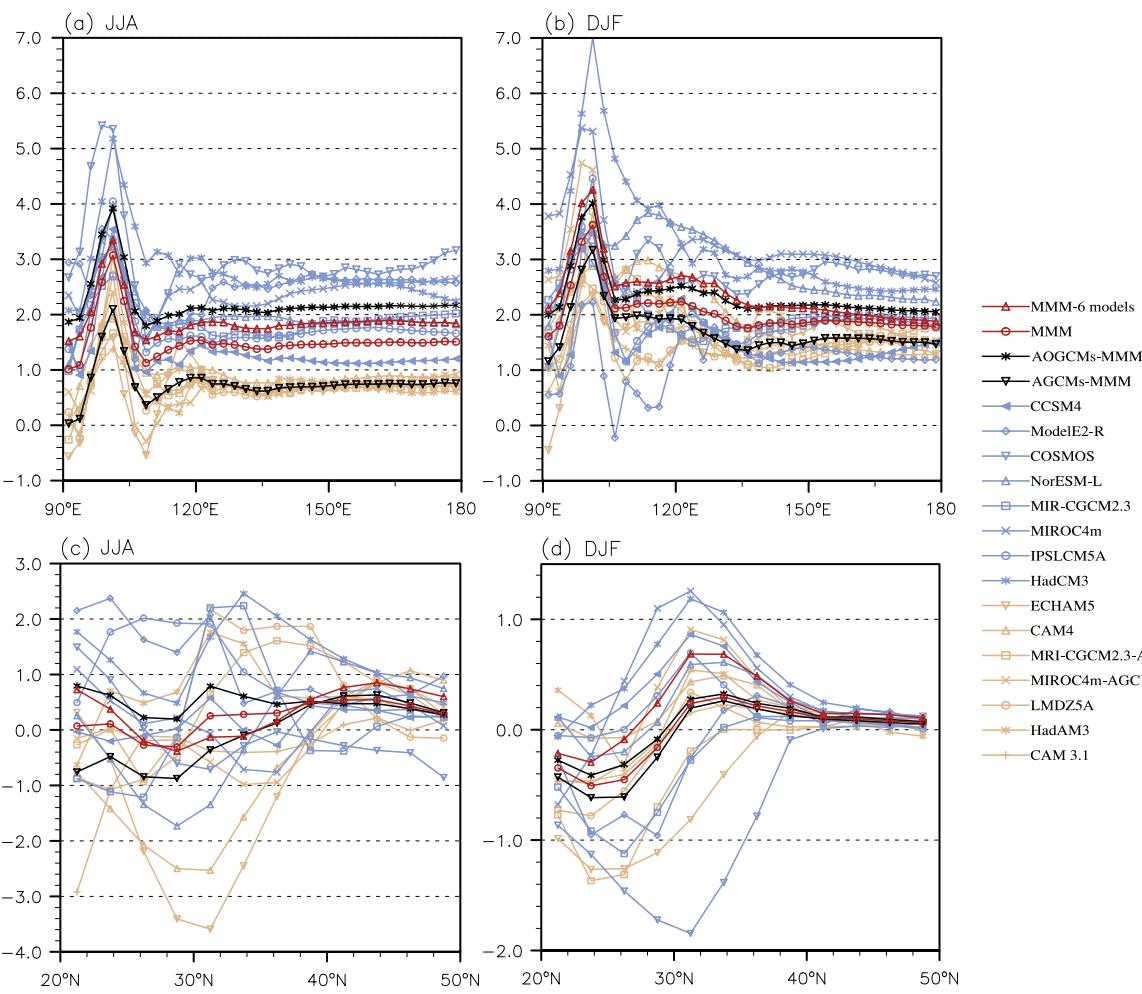

- MIR-CGCM
$-\quad$ MIROC $4 \mathrm{~m}$

$-\quad$ MIROC4m
$-\quad$ IPSLCM $5 \mathrm{~A}$

- $-\mathrm{HadCM} 3$

$\checkmark$ ECHAMS

$\triangle$ CAM4

口- MRI-CGCM2.3-AGCM

$x-$ MIROC4m-AGCM

- LMDZ5A

$*$ HadAM3
$\square \quad$ CAM 3.1

Fig. 9. The seasonal SAT (top, units: ${ }^{\circ} \mathrm{C}$ ) and precipitation differences (bottom, units: $\mathrm{mm}$ day ${ }^{-1}$ ) between mid-Pliocene and pre-industrial experiments. The SAT changes are meridionally averaged within $10-40^{\circ} \mathrm{N}$. The precipitation changes are zonally averaged within $105-$ $120^{\circ} \mathrm{E}$.
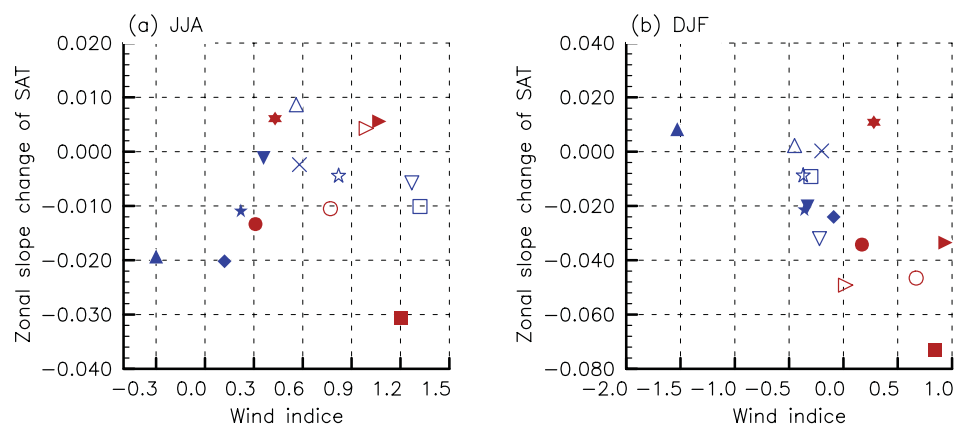

\section{$\rightarrow$ CCSM4 \\ $\Delta \cos \cos$ \\ $\checkmark$ MIR-CGCM2.3 \\ $\star$ IPSLCM5A \\ - HadCM3 \\ - NorESM-L \\ - MIROC4m}
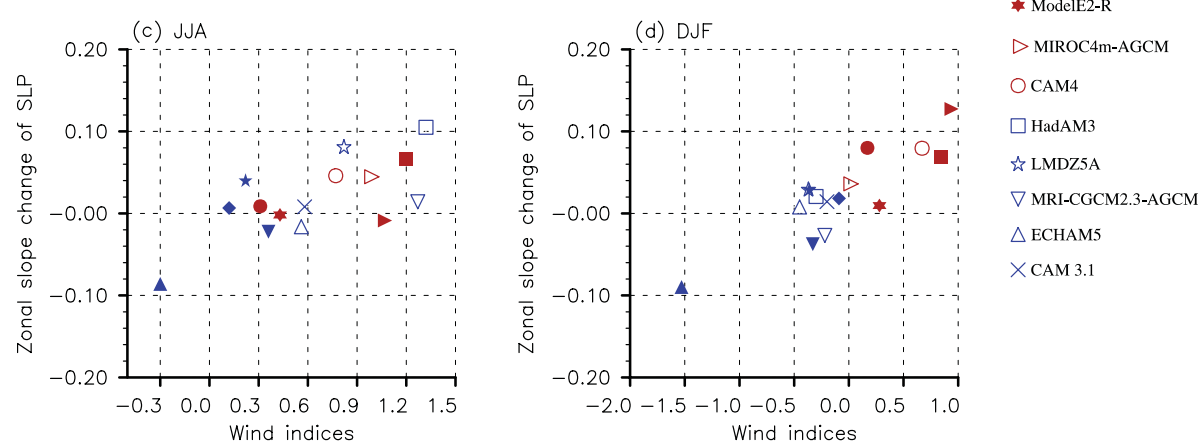

Fig. 10. Changes in zonal SLP and SAT slope averaged within the region of $10-40^{\circ} \mathrm{N}$ and $90-180^{\circ} \mathrm{E}$ versus changes in wind indices (units: $\mathrm{m} \mathrm{s}^{-1}$ ). The six models that simulate the weakened EAWW are shown in red. 
It is interesting that models in the PlioMIP have skill in simulating the EAWW in the pre-industrial experiments, but show substantial variation in simulating the EAWW in the warm mid-Pliocene. In contrast, these models have relatively low skills in simulating the EASW in the pre-industrial control experiments, but show almost consistent intensification in the mid-Pliocene EASW.

The reason behind this model behavior in simulating East Asian monsoon remains complicated. These models show different responses in the land-sea thermal contrast and SLP gradient to the increased surface radiative forcing, particularly in boreal winter. The different responses are likely related to independent changes in boundary conditions and/or physical processes and parameterizations in models. The changes in boundary conditions include modifications in atmospheric $\mathrm{CO}_{2}$ level, SSTs, topography and landcover/vegetation. The changes of atmospheric $\mathrm{CO}_{2}$ level can not be the cause, since all models use the identical atmospheric $\mathrm{CO}_{2}$ level $(405 \mathrm{ppmv})$ in the mid-Pliocene experiments and similar atmospheric $\mathrm{CO}_{2}$ levels $(\sim 280 \mathrm{ppmv})$ in the pre-industrial experiments. The SSTs can not be the cause either, as two of the six models that simulate weakened winter winds are atmosphere-only models, which use the same anomaly method to create the mid-Pliocene SSTs as other atmosphere-only models. Likewise, the topography is less likely to be the cause, as HadAM3 and HadCM3 have identical topography, but show different responses. Even so, due to different model resolutions, interpolating topography anomalies with a further smoothed method, which is used in creating mid-Pliocene topography conditions, may bring some uncertainties. The left possibility is the changes in landcover/vegetation conditions. Since each model group uses independent methods to create land-cover/vegetation conditions, the different land-cover/vegetation conditions could cause the large spread in the winter warming over China and the responses of EAWW simulated in the mid-Pliocene experiments. On the other hand, individual model sensitivities caused by physical processes and parameterizations in climate models are also a possible reason for the above discrepancy.

Nevertheless, some modifications in boundary conditions still can potentially reduce the discrepancy to some extent in the future PlioMIP simulations. The mid-Pliocene orbital parameters are identical to those used for the pre-industrial in the current PlioMIP. Yet, the PRISM reconstruction of midPliocene surface temperature is an average of multiple warm climates rather than a contemporaneous snapshot (Dowsett et al., 2010; Haywood et al., 2013). Such a warm climate signal might be better represented in climate models via prescription of a "warm" orbit. Therefore, in the simulations analyzed in this study, the heating over China during the midPliocene is likely underestimated in boreal winter. The higher topography condition used in the current mid-Pliocene experiments, which causes cooling in China, is still in conflict with the geological evidence that indicates uplifts on the mar- gin of Tibetan Plateau since the mid-Pliocene (e.g., Li and Fang, 1999; Zheng et al., 2000; Fang et al., 2005). The independent method in creating land-cover/vegetation conditions not only may cause the inconsistence between model groups, but also leads to the inconsistence within a group. For example, HadAM3 and HadCM3, which show spread in simulated EAWW, employ the same land-cover/vegetation conditions in their mid-Pliocene experiments, but different conditions in the pre-industrial control experiments. When an identical land-cover/vegetation condition is used in the pre-industrial experiments (Bragg et al., 2012), the discrepancy in EAWW simulated with HadCM3 and HadAM3 disappears. Seen in this way, a better topography reconstruction, orbital parameters that provide more heating in winter in the Northern Hemisphere, and more consistent land-cover/vegetation boundary conditions likely reduce the model-model differences in simulating East Asian monsoon climate during the mid-Pliocene.

In summary, based on the PlioMIP multi-model intercomparison, the mid-Pliocene climate of East Asia (focusing on China) is investigated from simulations with seven atmosphere-only models and eight coupled atmosphereocean models. The MMM of these models shows that summer winds largely strengthen in monsoon China, and winter winds strengthen in south monsoon China, but slightly weaken in north monsoon China. The simulated weakened winter winds and intensified summer winds agree well with geological reconstructions. The changes of winds in boreal summer and boreal winter are mainly caused by reorganization of the land-sea thermal contrast and SLP gradient between the East Asian continents and oceans. In addition, the MMM of all these models also illustrates a warmer and wetter mid-Pliocene climate in China, which agrees with most reconstructions in China. The mid-Pliocene SAT averaged over China is $2.64{ }^{\circ} \mathrm{C}$ higher than the pre-industrial, with a range of levels from $1.46^{\circ} \mathrm{C}$ to $4.49^{\circ} \mathrm{C}$ among individual models. The mid-Pliocene precipitation averaged over China is $0.25 \mathrm{~mm} \mathrm{day}^{-1}$ larger, with a range of levels from $-0.51 \mathrm{~mm} \mathrm{day}^{-1}$ to $0.75 \mathrm{~mm} \mathrm{day}^{-1}$ among individual models. However, the model-model discrepancy in simulating mid-Pliocene East Asian climate, in particular the midPliocene EAWW, can not be neglected. Six models simulated a weakened mid-Pliocene EAWW, whereas the other nine models did not. The reasons behind these model-model discrepancies are likely related to physical processes and parameterizations and/or the independent changes of boundary condition used in models.

\section{Supplementary material related to this article is

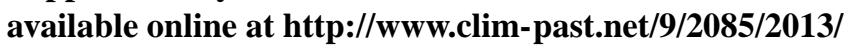 cp-9-2085-2013-supplement.pdf.}


Acknowledgements. This study was jointly supported by the Strategic Priority Research Program of the Chinese Academy of Sciences (Grant No. XDB03020602), the Strategic and Special Frontier Project of Science and Technology of the Chinese Academy of Sciences (Grant No. XDA05080803) and the National 973 Program of China (Grant No. 2010CB950102). B. L. Otto-Bliesner and N. A. Rosenbloom acknowledge that the research and computing for this project were supported by the U.S. National Science Foundation and Department of Energy. A. M. Haywood and A. M. Dolan acknowledge that the research leading to these results has received funding from the European Research Council under the European Union's Seventh Framework Programme (FP7/2007-2013)/ERC grant agreement no. 278636. A. M. Dolan acknowledges the UK Natural Environment Research Council (NERC) for the provision of a Doctoral Training Grant. D. J. Hill acknowledges the Leverhulme Trust for the provision of an early career fellowship with financial contributions made by the National Centre for Atmospheric Science and the British Geological Survey. W.-L. Chan and A. Abe-Ouchi acknowledge financial support from the Japan Society for the Promotion of Science and computing resources at the Earth Simulator Center, JAMSTEC. G. Lohmann received funding through the Helmholtz research programme PACES and the Helmholtz Climate Initiative REKLIM. C. Stepanek acknowledges financial support from the Helmholtz Graduate School for Polar and Marine Research and from REKLIM.

Edited by: C. Brierley

\section{References}

Bragg, F. J., Lunt, D. J., and Haywood, A. M.: Mid-Pliocene climate modelled using the UK Hadley Centre Model: PlioMIP Experiments 1 and 2, Geosci. Model Dev., 5, 1109-1125, doi:10.5194/gmd-5-1109-2012, 2012.

Cai, M. T., Fang, X. M., Wu, F. L., Miao, Y. F., and Appel, E.: Pliocene-Pleistocene stepwise drying of Central Asia: Evidence from paleomagnetism and sporopollen record of the deep borehole SG-3 in the western Qaidam Basin, NE Tibetan Plateau, Global Planet. Change, 94-95, 72-81, 2012.

Chan, W.-L., Abe-Ouchi, A., and Ohgaito, R.: Simulating the midPliocene climate with the MIROC general circulation model: experimental design and initial results, Geosci. Model Dev., 4, 1035-1049, doi:10.5194/gmd-4-1035-2011, 2011.

Chandler, M., Rind, D., and Thompson, R.: Joint investigations of the middle Pliocene climate II: GISS GCM Northern Hemisphere results, Global Planet. Change, 9, 197-219, 1994.

Chandler, M. A., Sohl, L. E., Jonas, J. A., Dowsett, H. J., and Kelley, M.: Simulations of the mid-Pliocene Warm Period using two versions of the NASA/GISS ModelE2-R Coupled Model, Geosci. Model Dev., 6, 517-531, doi:10.5194/gmd-6-517-2013, 2013.

Chao, W. C. and Chen, B.: The origin of monsoons, J. Atmos. Sci., 58, 3497-3507, 2001.

Contoux, C., Ramstein, G., and Jost, A.: Modelling the midPliocene Warm Period climate with the IPSL coupled model and its atmospheric component LMDZ5A, Geosci. Model Dev., 5, 903-917, doi:10.5194/gmd-5-903-2012, 2012.

Ding, Z. L., Yang, S. L., Sun, J. M., and Liu, T. S.: Iron geochemistry of loess and red clay deposits in the Chinese Loess Plateau and implications for long-term Asian monsoon evolution in the last 7.0 Ma, Earth Planet. Sc. Lett., 185, 99-109, 2001.

Dowsett, H. J., Thompson, R., Barron, J., Cronin, T., Fleming, F., Ishman, S., Poore, R., Willard, D., and Holtz, T.: Joint investigations of the middle Pliocene climate I: PRISM paleoenvironmental reconstructions, Global Planet. Change, 9, 169-195, 1994.

Dowsett, H. J., Barron, J. A., Poore, R. Z., Thompson, R. S., Cronin, T. M., Ishman, S. E., and Willard, D. A.: Middle Pliocene paleoenvironmental reconstruction: PRISM2, US Geol. Surv., Open File Rep., 99-535, 1999.

Dowsett, H. J., Robinson, M. M., and Foley, K. M.: Pliocene threedimensional global ocean temperature reconstruction, Clim. Past, 5, 769-783, doi:10.5194/cp-5-769-2009, 2009.

Dowsett, H., Robinson, M., Haywood, A., Salzmann, U., Hill, D., Sohl, L., Chandler, M., Williams, M., Foley, K., and Stoll, D.: The PRISM3D paleoenvironmental reconstruction, Stratigraphy, 7, 123-139, 2010.

Eronen, J. T., Puolamaki, K., Liu, L., Lintulaakso, K., Damuth, J., Janis, C., and Fortelius, M.: Precipitation and large herbivorous mammals II: application to fossil data, Evol. Ecol. Res., 12, 235248, 2010.

Fang, X. M., Zhao, Z. J., Li, J. J., Yan, M. D., Pan, B. T., Song, C. H., and Dai, S.: Magnetostratigraphy of the late Cenozoic Laojunmiao anticline in the northern Qilian Mountains and its implication for the northern Tibetan Plateau uplift, Sci. China, Ser. D: Earth Sci., 48, 1040-1051, 2005.

Ge, J. Y., Dai, Y., Zhang, Z. S., Zhao, D. A., Li, Q., Zhang, Y., Yi, L., Wu, H. B., Oldfield, F., and Guo, Z. T.: Major changes in East Asian climate in the mid-Pliocene: Triggered by the uplift of the Tibetan Plateau or global cooling?, J. Asian Earth Sci., 69, 48-59, 2013.

Guo, Z. T., Ruddiman, W. F., Hao, Q. Z., Wu, H. B., Qiao, Y. S., Zhu, R. X., Peng, S. Z., Wei, J. J., Yuan, B. Y., and Liu, T. S.: Onset of Asian desertifications by $22 \mathrm{Myr}$ ago inferred from loess deposits in China, Nature, 416, 159-163, 2002.

Han, J., Fyfe, W. S., Longstaffe, F. J., Palmer, H. C., Yan, F. H., and Mai, X. S.: Pliocene-Pleistocene climatic change recorded in fluviolacustrine sediments in central China, Palaeogeogr. Palaeocl., 135, 27-39, 1997.

Hao, H., Ferguson, D. K., Chang, H., and Li, C. S.: Vegetation and climate of the Lop Nur area, China, during the past 7 million years, Climatic Change, 113, 323-338, 2012.

Haywood, A. M. and Valdes, P. J.: Modelling Pliocene warmth: contribution of atmosphere, oceans and cryosphere, Earth Planet. Sc. Lett., 218, 363-377, 2004.

Haywood, A. M., Sellwood, B. W., and Valdes, P. J.: Regional warming: Pliocene (3 Ma) paleoclimate of Europe and the Mediterranean, Geology, 28, 1063-1066, 2000.

Haywood, A. M., Dowsett, H. J., Otto-Bliesner, B., Chandler, M. A., Dolan, A. M., Hill, D. J., Lunt, D. J., Robinson, M. M., Rosenbloom, N., Salzmann, U., and Sohl, L. E.: Pliocene Model Intercomparison Project (PlioMIP): experimental design and boundary conditions (Experiment 1), Geosci. Model Dev., 3, 227-242, doi:10.5194/gmd-3-227-2010, 2010.

Haywood, A. M., Dowsett, H. J., Robinson, M. M., Stoll, D. K., Dolan, A. M., Lunt, D. J., Otto-Bliesner, B., and Chandler, M. A.: Pliocene Model Intercomparison Project (PlioMIP): experimental design and boundary conditions (Experiment 2), Geosci. Model Dev., 4, 571-577, doi:10.5194/gmd-4-571-2011, 2011. 
Haywood, A. M., Hill, D. J., Dolan, A. M., Otto-Bliesner, B. L., Bragg, F., Chan, W.-L., Chandler, M. A., Contoux, C., Dowsett, H. J., Jost, A., Kamae, Y., Lohmann, G., Lunt, D. J., Abe-Ouchi, A., Pickering, S. J., Ramstein, G., Rosenbloom, N. A., Salzmann, U., Sohl, L., Stepanek, C., Ueda, H., Yan, Q., and Zhang, Z.: Large-scale features of Pliocene climate: results from the Pliocene Model Intercomparison Project, Clim. Past, 9, 191-209, doi:10.5194/cp-9-191-2013, 2013.

Hoskins, B. J. and Rodwell, M. J.: A model of the Asian summer monsoon. Part I: The global scale, J. Atmos. Sci., 52, 1329-1340, 1995.

Jian, Z. M., Zhao, Q. H., Cheng, X. R., Wang, J. L., Wang, P. X., and $\mathrm{Su}, \mathrm{X}$.: Pliocene-Pleistocene stable isotope and paleoceanographic changes in the northern South China Sea, Palaeogeogr. Palaeocl., 193, 425-442, 2003.

Jiang, D. and Lang, X.: Last glacial maximum East Asian monsoon: Results of PMIP simulations, J. Climate, 23, 5030-5038, 2010.

Jiang, D., Wang, H. J., Ding, Z. L., Lang, X., and Drange, H.: Modeling the middle Pliocene climate with a global atmospheric general circulation model, J. Geophys. Res., 110, D14107, doi:10.1029/2004JD005639, 2005.

Jiang, H. C. and Ding, Z. L.: A 20 Ma pollen record of EastAsian summer monsoon evolution from Guyuan, Ningxia, China, Palaeogeogr. Palaeocl., 265, 30-38, 2008.

Jiang, H. C. and Ding, Z. L.: Eolian grain-size signature of the Sikouzi lacustrine sediments (Chinese Loess Plateau): Implications for Neogene evolution of the East Asian winter monsoon, Geol. Soc. Am. Bull., 122, 843-854, 2010.

Kamae, Y. and Ueda, H.: Mid-Pliocene global climate simulation with MRI-CGCM2.3: set-up and initial results of PlioMIP Experiments 1 and 2, Geosci. Model Dev., 5, 793-808, doi:10.5194/gmd-5-793-2012, 2012.

Kanamitsu, M., Ebisuzaki, W., Woollen, J., Yang, S. K., Hnilo, J. J., Fiorino, M., and Potter, G. L.: NCEP-DOE AMIP-II reanalysis (R-2), B. Am. Meteorol. Soc., 83, 1631-1643, 2002.

Kou, X. Y., Ferguson, D. K., Xu, J. X., Wang, Y. F., and Li, C. S.: The reconstruction of paleovegetation and paleoclimate in the Late Pliocene of west Yunnan, China, Climatic Change, 77, 431448, 2006.

Li, B. H., Wang, J. L., Huang, B. Q., Li, Q. Y., Jian, Z. M., Zhao, Q. H., Su, X., and Wang, P. X.: South China Sea surface water evolution over the last 12 Myr: A south-north comparison from Ocean Drilling Program Sites 1143 and 1146, Paleoceanography, 19, PA1009, doi:10.1029/2003PA000906, 2004a.

Li, J. J. and Fang, X. M.: Uplift of the Tibetan Plateau and environmental changes, Chinese Sci. Bull., 44, 2117-2124, 1999.

Li, X. Q., Li, C. S., Lu, H. Y., Dodson, J. R., and Wang, Y. F.: Paleovegetation and paleoclimate in middle-late Pliocene, Shanxi, central China, Palaeogeogr. Palaeocl., 210, 57-66, 2004b.

Liu, G. W., Leopold, E. B., Liu, Y., Wang, W. M., Yu, Z. Y., and Tong, G. B.: Palynological record of Pliocene climate events in North China, Rev. Palaeobot. Palyno., 119, 335-340, 2002.

Lunt, D. J., Haywood, A. M., Schmidt, G. A., Salzmann, U., Valdes, P. J., and Dowsett, H. J.: Earth system sensitivity inferred from Pliocene modelling and data, Nat. Geosci., 3, 60-64, 2010.

Ma, Y. Z., Wu, F. L., Fang, X. M., Li, J. J., An, Z. S., and Wang, W.: Pollen record from red clay sequence in the central Loess Plateau between 8.10 and 2.60 Ma, Chinese Sci. Bull., 50, 22342243, 2005.
Ramage, C. S.: Monsoon meteorology, Academic Press, New York, 1971.

Robinson, M. M., Valdes, P. J., Haywood, A. M., Dowsett, H. J., Hill, D. J., and Jones, S. M.: Bathymetric controls on Pliocene North Atlantic and Arctic sea surface temperature and deepwater production, Palaeogeogr. Palaeocl., 309, 92-97, 2011.

Rosenbloom, N. A., Otto-Bliesner, B. L., Brady, E. C., and Lawrence, P. J.: Simulating the mid-Pliocene Warm Period with the CCSM4 model, Geosci. Model Dev., 6, 549-561, doi:10.5194/gmd-6-549-2013, 2013.

Salzmann, U., Haywood, A. M., Lunt, D. J., Valdes, P. J., and Hill, D. J.: A new global biome reconstruction and data-model comparison for the middle Pliocene, Global Ecol. Biogeogr., 17, 432447, 2008.

Sloan, L. C., Crowley, T. J., and Pollard, D.: Modeling of middle Pliocene climate with the NCAR GENESIS general circulation model, Mar. Micropaleontol., 27, 51-61, 1996.

Sohl, L. E., Chandler, M. A., Schmunk, R. B., Mankoff, K., Jonas, J. A., Foley, K. M., and Dowsett, H. J.: PRISM3/GISS topographic reconstruction, US Geol. Surv. Data Serie 419, 2009.

Stepanek, C. and Lohmann, G.: Modelling mid-Pliocene climate with COSMOS, Geosci. Model Dev., 5, 1221-1243, doi:10.5194/gmd-5-1221-2012, 2012.

Sun, B. N., Wu, J. Y., Liu, Y. S., Ding, S. T., Li, X. C., Xie, S. P., Yan, D. F., and Lin, Z. C.: Reconstructing Neogene vegetation and climates to infer tectonic uplift in western Yunnan, China, Palaeogeogr. Palaeocl., 304, 328-336, 2011.

Sun, D. H., Su, R. X., Bloemendal, J., and Lu, H. Y.: Grain-size and accumulation rate records from Late Cenozoic aeolian sequences in northern China: Implications for variations in the East Asian winter monsoon and westerly atmospheric circulation, Palaeogeogr. Palaeocl., 264, 39-53, 2008.

Taylor, K. E.: Summarizing multiple aspects of model performance in a single diagram, J. Geophys. Res., 106, 7183-7192, 2001.

Uppala, S. M., Kallberg, P. W., Simmons, A. J., Andrae, U., Bechtold, V. D., Fiorino, M., Gibson, J. K., Haseler, J., Hernandez, A., Kelly, G. A., Li, X., Onogi, K., Saarinen, S., Sokka, N., Allan, R. P., Andersson, E., Arpe, K., Balmaseda, M. A., Beljaars, A. C. M., Van De Berg, L., Bidlot, J., Bormann, N., Caires, S., Chevallier, F., Dethof, A., Dragosavac, M., Fisher, M., Fuentes, M., Hagemann, S., Holm, E., Hoskins, B. J., Isaksen, L., Janssen, P. A. E. M., Jenne, R., McNally, A. P., Mahfouf, J. F., Morcrette, J. J., Rayner, N. A., Saunders, R. W., Simon, P., Sterl, A., Trenberth, K. E., Untch, A., Vasiljevic, D., Viterbo, P., and Woollen, J.: The ERA-40 re-analysis, Q. J. Roy. Meteor. Soc., 131, 29613012, 2005.

Wan, S. M., Li, A. C., Clift, P. D., and Stuut, J. B. W.: Development of the East Asian monsoon: Mineralogical and sedimentologic records in the northern South China Sea since 20 Ma, Palaeogeogr. Palaeocl., 254, 561-582, 2007.

Wang, W. M., Li, J. R., Wang, J. D., and He, Z. J.: Palynofloras from Pliocene balouhe formation and Pleistocene in Zhangqiu County, Shandong Province, Acta Palaeonotol. Sin., 41, 72-76, 2002 (in Chinese with English abstract).

Wang, Y. F., Wang, B., and Oh, J.-H.: Impacts of the preceding El Niño on the East Asian summer atmospheric circulation, J. Meteor. Soc. Japan, 79, 575-588, 2001.

Webster, P. J., Magaña, V. O., Palmer, T. N., Shukla, J., Tomas, R. A., Yanai, M., and Yasunari, T.: Monsoons: Processes, pre- 
dictability, and the prospects for prediction, J. Geophys. Res., 103, 14451-14510, 1998.

Wu, A. and Ni, Y.: The influence of Tibetan Plateau on the interannual variability of Asian monsoon, Adv. Atmos. Sci., 14, 491504, 1997.

Wu, F. L., Fang, X., Ma, Y., Herrmann, M., Mosbrugger, V., An, Z., and Miao, Y.: Plio-Quaternary stepwise drying of Asia: Evidence from a 3-Ma pollen record from the Chinese Loess Plateau, Earth Planet. Sc. Lett., 257, 160-169, 2007.

Wu, F. L., Fang, X. M., Herrmann, M., Mosbrugger, V., and Miao, Y. F.: Extended drought in the interior of Central Asia since the Pliocene reconstructed from sporopollen records, Global Planet. Change, 76, 16-21, 2011.

Wu, N. Q., Pei, Y. P., Lu, H. Y., Guo, Z. T., Li, F. J., and Liu, T. S.: Marked ecological shifts during 6.2-2.4 Ma revealed by a terrestrial molluscan record from the Chinese Red Clay Formation and implication for palaeoclimatic evolution, Palaeogeogr. Palaeocl., 233, 287-299, 2006.

Wu, Y. S.: Palynoflora at late Miocene-early Pliocene from leijiahe of lingtai, Gansu Province, China, Acta Bot. Sin., 43, 750-756, 2001 (in Chinese with English abstract).

Xie, P. P. and Arkin, P. A.: Analyses of global monthly precipitation using gauge observations, satellite estimates, and numerical model predictions, J. Climate, 9, 840-858, 1996.

Xie, S., Sun, B., Wu, J., Lin, Z., Yan, D., and Xiao, L.: Palaeoclimatic estimates for the Late Pliocene based on leaf physiognomy from western Yunnan, China, Turk. J. Earth Sci., 21, 251-261, 2012.

Xiong, S. F., Ding, Z. L., and Yang, S. L.: Abrupt shifts in the late Cenozoic environment of north-western China recorded in loesspalaeosol-red clay sequences, Terra Nova, 13, 376-381, 2001.
Yan, Q., Zhang, Z. S., Wang, H. J., Jiang, D., and Zheng, W. P.: Simulation of sea surface temperature changes in the middle Pliocene warm period and comparison with reconstructions, Chinese Sci. Bull., 56, 890-899, 2011.

Yan, Q., Zhang, Z. S., and Gao, Y. Q.: An East Asian monsoon in the mid-Pliocene, Atmos. Oceanic Sci. Lett., 5, 449-454, 2012a.

Yan, Q., Zhang, Z. S., Wang, H. J., Gao, Y. Q., and Zheng, W. P.: Set-up and preliminary results of mid-Pliocene climate simulations with CAM3.1, Geosci. Model Dev., 5, 289-297, doi:10.5194/gmd-5-289-2012, 2012 b.

Yao, Y. F., Bruch, A. A., Cheng, Y. M., Mosbrugger, V., Wang, Y. F., and Li, C. S.: Monsoon versus uplift in southwestern ChinaLate Pliocene climate in Yuanmou Basin, Yunnan, PLoS ONE, 7, e37760. doi:37710.31371/journal.pone.0037760, 2012.

Zhang, Z. and Yan, Q.: Pre-industrial and mid-Pliocene simulations with NorESM-L: AGCM simulations, Geosci. Model Dev., 5, 1033-1043, doi:10.5194/gmd-5-1033-2012, 2012.

Zhang, Z. S., Nisancioglu, K., Bentsen, M., Tjiputra, J., Bethke, I., Yan, Q., Risebrobakken, B., Andersson, C., and Jansen, E.: Pre-industrial and mid-Pliocene simulations with NorESM-L, Geosci. Model Dev., 5, 523-533, doi:10.5194/gmd-5-523-2012 , 2012.

Zhang, Z. S., Nisancioglu, K. H., and Ninnemann, U. S.: Increased ventilation of Antarctic deep water during the warm midPliocene, Nat. Commun., 4, doi:10.1038/ncomms2521, 2013.

Zhao, L. C., Collinson, M. E., and Li, C. S.: Fruits and seeds of Ruppia (Potamogetonaceae) from the Pliocene of Yushe Basin, Shanxi, northern China and their ecological implications, Bot. J. Linn. Soc., 145, 317-329, 2004.

Zheng, H. B., Powell, C. M., and An, Z. S.: Pliocene uplift of the northern Tibetan Plateau, Geology, 28, 715-718, 2000. 